OPEN ACCESS

Edited by:

Federico Cesano,

Università degli Studi di Torino, Italy

Reviewed by:

Pimpa Hormnirun,

Kasetsart University, Thailand Jincai Wu,

Lanzhou University, China Salah S. Massoud, University of Louisiana at Lafayette, United States

*Correspondence: Ming-Tsz Chen mschen@pu.edu.tw Chi-Tien Chen

ctchen@dragon.nchu.edu.tw

Specialty section

This article was submitted to Inorganic Chemistry,

a section of the journal

Frontiers in Chemistry

Received: 27 September 2018 Accepted: 28 November 2018

Published: 04 January 2019

Citation:

Chen M-T, Chen Y-Y, Li G-L and Chen C-T (2019) Diverse Coordinative

Zinc Complexes Containing Amido-Pyridinate Ligands: Structural and Catalytic Studies. Front. Chem. 6:615

doi: 10.3389/fchem.2018.00615

\section{Diverse Coordinative Zinc Complexes Containing Amido-Pyridinate Ligands: Structural and Catalytic Studies}

\author{
Ming-Tsz Chen ${ }^{1 *}$, Yu-Yang Chen ${ }^{1}$, Guan-Lin Li ${ }^{1}$ and Chi-Tien Chen ${ }^{2 *}$ \\ ${ }^{1}$ Department of Applied Chemistry, Providence University, Taichung, Taiwan, ${ }^{2}$ Department of Chemistry, National Chung \\ Hsing University, Taichung, Taiwan
}

In this work, zinc complexes containing amidopyridinate ligands substituted with different pendant arms have been described. Treatment of ligand precursors with $\mathrm{ZnEt}_{2}$ at a 1:1 ratio in THF yields zinc ethyl complexes $\left(\mathrm{PyNC}_{1}^{\mathrm{Py}}\right)_{2}(\mathrm{ZnEt})_{2}(\mathbf{1})$ and $\left(\mathrm{PyNC}_{2}^{\mathrm{NMe}}\right)_{2}(\mathrm{ZnEt})_{2}(\mathbf{2})$, respectively. Complexes $\mathbf{1}$ and $\mathbf{2}$ show the same geometry as a distorted tetrahedron, but adopt different coordination behaviors supported by the ligands. Complex $\mathbf{1}$ represents a rare and a non-centrosymmetric mode, which the amido group bridges two zinc centers to form a six-membered ring. However, complex 2 shows a centrosymmetric mode, which the pyridine group links to the zinc centers to form an eight-membered ring. Recrystallization of complex $\mathbf{2}$ gives an additional complex $\left(\mathrm{PyNC}_{2}^{\mathrm{NMe} 2}\right)_{4} \mathrm{Zn}_{3}\left(\mu^{3}-\mathrm{O}\right)(\mathbf{3})$. We attempted to prepare zinc benzyl oxide complexes but afforded only a self-assembly cubane complex $\mathrm{Zn}_{7} \mathrm{Et}_{6}(\mathrm{OBn})_{8}$ (4). All molecular structures 1-4 are characterized depending on both single-crystal X-ray and spectroscopic data. Furthermore, their catalytic properties toward the ring opening polymerization of $\varepsilon$-caprolactone and L-lactide, using benzyl alcohol as the initiation reagent, are under investigation.

Keywords: amidopyridinate ligands, amination reaction, zinc complexes, ring opening polymerization, biodegradable polymers, biocompatibility polymers

\section{INTRODUCTION}

The role of polyesters has been given much attention due to their essential characteristics of being biodegradable, biocompatible, and permeable (Puelacher et al., 1994; Cheng et al., 1999). Owing to the promising applications of these polyesters, numerous groups have investigated and developed catalytic systems for generating polyesters by ring opening polymerization. Various kinds of metal complexes, such as $\mathrm{Al}, \mathrm{Mg}, \mathrm{Zn}, \mathrm{Fe}$, and $\mathrm{Sn}$, have been well-studied as initiators/catalysts and control very well the molecular properties of the polymers (O'keefe et al., 2001; Coates, 2002; Nakano et al., 2003; Chisholm and Zhou, 2004; Coates and Moore, 2004; Wu et al., 2006; Wheaton et al., 2009). Low-toxic and environmentally friendly metal centers such as magnesium, calcium, and zinc are fascinating candidates with a crucial role in aiding to synthesize compounds with ancillary ligands (Wheaton et al., 2009). However, undesirable side reactions such as backbiting or transesterification often occur as a result of forming macrocycles over a wide range of molecular weight. Employing a steric bulky ligand or pendant arm(s) coordinated to an active metal center provides a barrier to hinder these undesired polymers. As a result of the successful application of $\beta$-diketiminate (BDI) complexes in ring opening polymerization, alternative or 
structurally similar ligand precursors are extensively studied. Recently, several systems have been checked for catalytic properties in ring opening polymerization (Cheng et al., 2000; Hill and Hitchcock, 2002; Gamer et al., 2005; Kröger et al., 2005, 2006; Lee et al., 2005; Vitanova et al., 2005; Alaaeddine et al., 2006; Chen et al., 2007, 2009, 2014; Liu et al., 2007; Wiecko et al., 2007; Gong and Ma, 2008; Yao et al., 2008; Peng and Chen, 2009; Chen and Chen, 2011; Peng et al., 2015). We are particularly motivated by the interest of the ligand precursors supported with parallel chelating systems and exhibited iso-electronic characteristics related to amidinato ligands. Our previous studies have focused on amidopyridine (Chen and Chen, 2017), and this article represents an extension of this work to investigate different substituent functional ligand precursors. According to our previous work on ring opening polymerization, the anilido-oxazolinate system (Chen et al., 2007, 2009; Chen and Chen, 2011), anilido-pyrazolate system (Peng and Chen, 2009), sulfon-amido-oxazolinate/pyrazolinate system (Chen et al., 2014), and the benzamidnated system (Wu et al., 2005) showed good activity; this is in addition to the $\beta$ diketiminate (BDI) zinc complex systems demonstrated by other groups (Cheng et al., 2000; Hill and Hitchcock, 2002; Gamer et al., 2005; Kröger et al., 2005, 2006; Lee et al., 2005; Vitanova et al., 2005; Alaaeddine et al., 2006; Chen et al., 2007, 2009, 2014; Liu et al., 2007; Wiecko et al., 2007; Gong and Ma, 2008; Yao et al., 2008; Peng and Chen, 2009; Chen and Chen, 2011; Peng et al., 2015). Hence, amidopyridinate zinc complexes are envisioned to be active players in ring opening polymerization. In support of this possibility, the preparation of zinc complexes supported with amido-pyridinate ligands has been investigated in this paper. Both coordination behaviors and catalytic activities in ring opening polymerization of L-lactide and $\varepsilon$-caprolactone by using benzyl alcohol as the initiation reagent are also under investigation.

\section{MATERIALS AND METHODS}

\section{Reagents and Methods}

All manipulations were carried out under an atmosphere of dinitrogen using standard Schlenk-line or dry box techniques. Solvents were refluxed over the appropriate drying agent and distilled prior to use. DMSO (Dimethyl sulfoxide, TEDIA) was used as supplied. Deuterated solvents were dried over molecular sieves. $\mathrm{ZnEt}_{2}$ (Aldrich, $1.0 \mathrm{M}$ in hexane), $\mathrm{CuI}$ (Strem), $\mathrm{K}_{3} \mathrm{PO}_{4}$ (Lancaster), L-proline (Alfa), N,N-dimethylethyleneamine (Acros), and 2-(aminomethyl) pyridine (Acros) were used as supplied. Benzyl alcohol was dried over magnesium sulfate and distilled before use. $\varepsilon$-Caprolactone was dried over magnesium sulfate and L-Lactide was recrystallized from toluene prior to use.

${ }^{1} \mathrm{H}$ and ${ }^{13} \mathrm{C}\left\{{ }^{1} \mathrm{H}\right\}$ NMR spectra were recorded either on Varian Mercury-400 (400 MHz) or Brucker-AV-400 (400 $\mathrm{MHz}$ ) spectrometers in chloroform- $d$ at ambient temperature unless stated otherwise and referenced internally to the residual solvent peak and reported as parts per million relative to tetramethylsilane. Elemental analyses were performed by Elementar Vario ELIV or FLASH 2000 Series Nitrogen and a Carbon Analyzer instrument (Thermo).
The GPC measurements were performed in $\mathrm{THF}$ at $35^{\circ} \mathrm{C}$ with a Waters 1515 isocratic HPLC pump, a Waters 2414 refractive index detector, and Waters styragel column (HR4E). Molecular weights and molecular weight distributions were calculated using polystyrene as standard. The synthesis of the ligands and complexes is described in detail in the Supplementary Material in addition to the spectroscopic data. In a similar fashion, the details of the X-ray data can be found in the Supplementary Material.

\section{Ligand Synthesis}

\section{$\mathrm{HNPyC}_{1}^{\mathrm{Py}}$ (Foxon et al., 2002)}

To a Schlenk flask containing 2-bromopyridine $(0.48 \mathrm{~mL}, 5$ mmol), 2-(aminomethyl) pyridine $(0.77 \mathrm{~mL}, 7.5 \mathrm{mmol}), \mathrm{K}_{3} \mathrm{PO}_{4}$ (2.12 g, $10 \mathrm{mmol})$, CuI (0.1 g, $0.5 \mathrm{mmol}), L$-proline $(0.12 \mathrm{~g}, 1$ $\mathrm{mmol}), 3.5 \mathrm{~mL}$ DMSO was added at room temperature. The reaction mixture was heated to $110^{\circ} \mathrm{C}$ for $17 \mathrm{~h}$. The resulting dark-brown solution was extracted with $\mathrm{EA} / \mathrm{H}_{2} \mathrm{O}$ three times. The organic layer was dried over $\mathrm{Na}_{2} \mathrm{SO}_{4}$ and filtered. All volatiles were removed in vacuum to yield a yellow oily liquid product. Crude product was purified by flash column chromatography on silica gel (hexane/EA=1:1 then methanol) to give a yellow liquid (The first band). Yield $1.36 \mathrm{~g}, 73 \% .{ }^{1} \mathrm{H} \mathrm{NMR}$ $\left(\mathrm{CDCl}_{3}, 400 \mathrm{MHz}\right) \delta 4.67\left(\mathrm{~d}, \mathrm{CH}_{2}, J=5.6 \mathrm{~Hz}, 2 \mathrm{H}\right), 5.59(\mathrm{br}, \mathrm{NH}$, $1 \mathrm{H}), 6.47(\mathrm{~d}, \mathrm{CH}-\mathrm{Py}, J=8.4 \mathrm{~Hz}, 1 \mathrm{H}), 6.60(\mathrm{t}, \mathrm{CH}-\mathrm{Py}, J=6 \mathrm{~Hz}$, $1 \mathrm{H}), 7.20(\mathrm{t}, \mathrm{CH}-\mathrm{Py}, J=6.2 \mathrm{~Hz}, 1 \mathrm{H}), 7.34(\mathrm{~d}, \mathrm{CH}-\mathrm{Py}, J=7.6 \mathrm{~Hz}$, $1 \mathrm{H}), 7.41(\mathrm{t}, \mathrm{CH}-\mathrm{Py}, J=6.8 \mathrm{~Hz}, 1 \mathrm{H}), 7.66(\mathrm{t}, \mathrm{CH}-\mathrm{Py}, J=7.6 \mathrm{~Hz}$, $1 \mathrm{~Hz}), 8.12(\mathrm{t}, \mathrm{CH}-\mathrm{Py}, J=4 \mathrm{~Hz}, 1 \mathrm{H}), 8.57(\mathrm{t}, \mathrm{CH}-\mathrm{Py}, J=4.8 \mathrm{~Hz}$, 1H). ${ }^{13} \mathrm{C}\left\{{ }^{1} \mathrm{H}\right\}$ NMR $\left(\mathrm{CDCl}_{3}, 100 \mathrm{MHz}\right) \delta 46.9\left(\mathrm{~s}, \mathrm{CH}_{2}\right), 107.4$, 112.6, 121.3, 121.7, 136.3, 136.9, 147.7, 148.7(eight $\mathrm{CH}-\mathrm{Py}), 158.1$, 158.3(two tert- $C$-Py).

\section{HNPyC $_{2}^{\mathrm{NMe} 2}$ (Gogate et al., 2014)}

The procedure for the preparation of $\mathrm{HNPyC}_{2}^{\mathrm{NMe} 2}$ was similar to that used for $\mathrm{HNPyC}_{1}^{\mathrm{Py}}$ but with 2-bromopyridine $(0.96 \mathrm{~mL}, 10$ mmol), $N, N$-dimethylethyleneamine (3.28 mL, $30 \mathrm{mmol}), \mathrm{K}_{3} \mathrm{PO}_{4}$ (4.26 g, $20 \mathrm{mmol})$, CuI $(0.19 \mathrm{~g}, 1 \mathrm{mmol})$, and $L$-proline $(0.24 \mathrm{~g}, 2$ $\mathrm{mmol}$ ), and $8 \mathrm{~mL}$ DMSO. Crude product was purified by flash column chromatography on silica gel (hexane/EA $=1: 1$ then methanol) to give a yellow liquid (The first band). Yield $2.26 \mathrm{~g}$, 91\%. ${ }^{1} \mathrm{H} \mathrm{NMR}\left(\mathrm{CDCl}_{3}, 400 \mathrm{MHz}\right) \delta 2.26\left(\mathrm{~s}, \mathrm{~N}\left(\mathrm{CH}_{3}\right)_{2}, 6 \mathrm{H}\right)$, 2.54(t, $\left.\mathrm{NCH}_{2}, J=6 \mathrm{~Hz}, 2 \mathrm{H}\right), 3.36\left(\mathrm{t}, \mathrm{CH}_{2} \mathrm{NMe}_{2}, J=5.6 \mathrm{~Hz}, 2 \mathrm{H}\right)$, $5.00(\mathrm{~s}, \mathrm{NH}, 1 \mathrm{H}), 6.40(\mathrm{~d}, \mathrm{CH}-\mathrm{Py}, J=8.4 \mathrm{~Hz}, 1 \mathrm{H}), 6.54(\mathrm{t}, \mathrm{CH}-\mathrm{Py}$, $J=6.2 \mathrm{~Hz}, 1 \mathrm{H}), 7.40(\mathrm{t}, \mathrm{CH}-\mathrm{Py}, J=8.6 \mathrm{~Hz}, 1 \mathrm{H}), 8.08(\mathrm{~d}, \mathrm{CH}-\mathrm{Py}$, $J=5.2 \mathrm{~Hz}, 1 \mathrm{H}) .{ }^{13} \mathrm{C}\left\{{ }^{1} \mathrm{H}\right\} \mathrm{NMR}\left(\mathrm{CDCl}_{3}, 100 \mathrm{MHz}\right) \delta 39.3\left(\mathrm{~s}, \mathrm{CH}_{2}\right)$, $45.2\left(\mathrm{~s}, \mathrm{~N}\left(\mathrm{CH}_{3}\right)_{2}\right), 58.0\left(\mathrm{~s}, \mathrm{CH}_{2}\right), 107.4,112.5,137.1,148.1$ (four CH-Py), 158.8(one tert-C-Py).

\section{Synthesis of Zinc Complexes $\left(\mathrm{NPyC}_{1}^{\mathrm{Py}}\right)_{2}(\mathrm{ZnEt})_{2}(1)$}

To a flask containing $\mathrm{HNPyC}_{1}^{\mathrm{Py}}(0.37 \mathrm{~g}, 2 \mathrm{mmol})$ and $15 \mathrm{~mL}$ hexane, $2.2 \mathrm{~mL} \mathrm{ZnEt}_{2}$ (1M in hexanes, $2.2 \mathrm{mmol}$ ) was added at $0^{\circ} \mathrm{C}$. The reaction mixture was allowed to warm to room temperature and reacted overnight. After $12 \mathrm{~h}$ of stirring, the yellow suspension solution was filtered and the residue was washed with hexane to afford a pale-yellow solid. Yield $0.38 \mathrm{~g}$, 69\%. ${ }^{1} \mathrm{H} \mathrm{NMR}\left(\mathrm{CDCl}_{3}, 400 \mathrm{MHz}\right) \delta-0.11\left(\mathrm{~s}, \mathrm{ZnCH}_{2} \mathrm{CH}_{3}, 2 \mathrm{H}\right)$, 


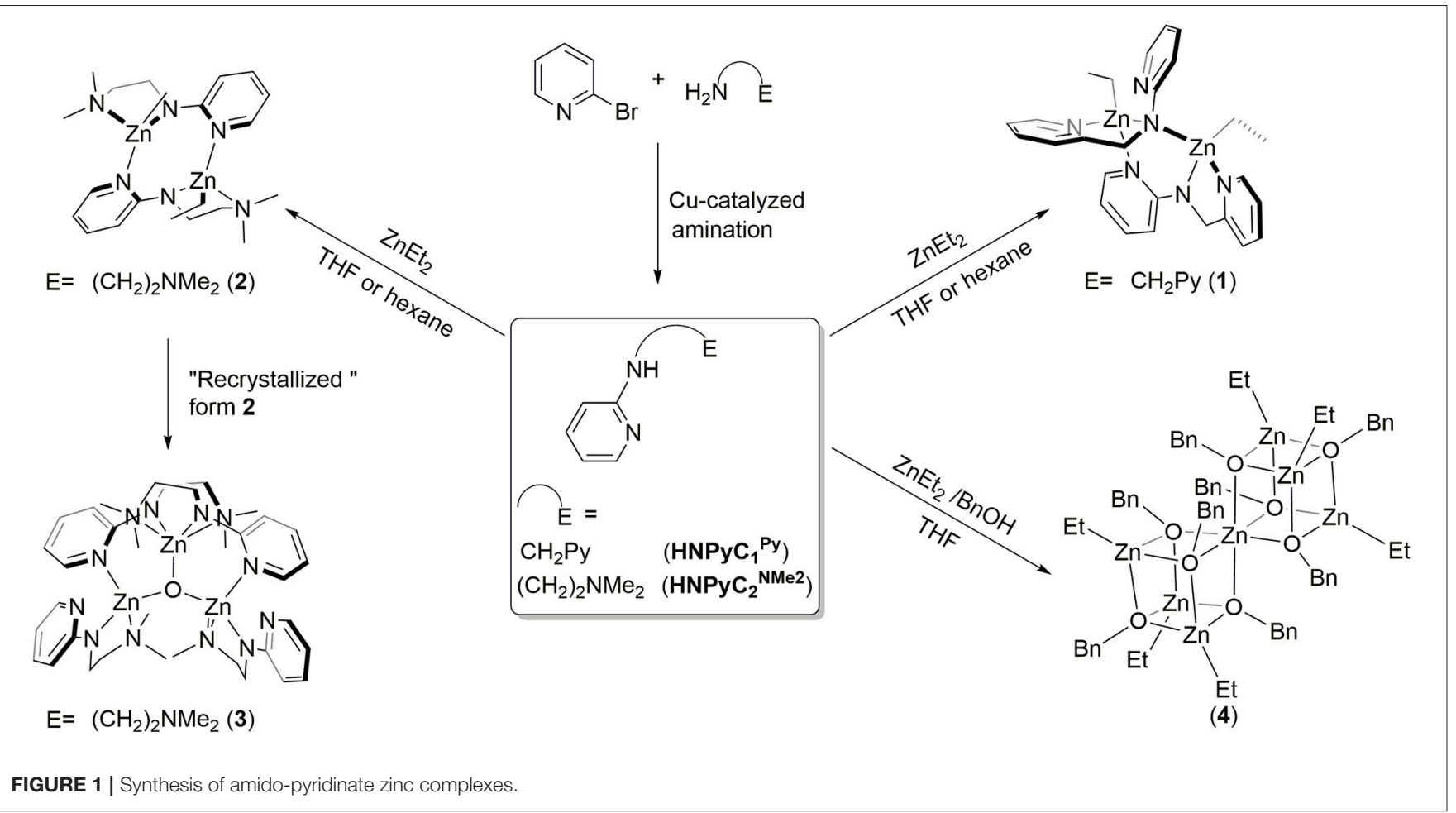

0.88(m, $\left.\mathrm{ZnCH}_{2} \mathrm{CH}_{3}, 3 \mathrm{H}\right), 4.59\left(\mathrm{~s}, \mathrm{CH}_{2}, 2 \mathrm{H}\right), 6.31(\mathrm{t}, \mathrm{CH}-\mathrm{Py}$, $J=6 \mathrm{~Hz}, 1 \mathrm{H}), 6.61(\mathrm{~d}, \mathrm{CH}-\mathrm{Py}, J=8.4 \mathrm{~Hz}, 1 \mathrm{H}), 7.16(\mathrm{~m}, \mathrm{CH}-\mathrm{Py}$, 2H), 7.29(d, CH-Py, $J=8 \mathrm{~Hz}, 1 \mathrm{H}), 7.69(\mathrm{t}, \mathrm{CH}-\mathrm{Py}, J=7.6 \mathrm{~Hz}$, $1 \mathrm{H}), 7.95(\mathrm{~d}, \mathrm{CH}-\mathrm{Py}, J=4.4 \mathrm{~Hz}, 1 \mathrm{H}), 8.13(\mathrm{~d}, \mathrm{CH}-\mathrm{Py}, J=4.4 \mathrm{~Hz}$, 1H). ${ }^{13} \mathrm{C}\left\{{ }^{1} \mathrm{H}\right\} \mathrm{NMR}\left(\mathrm{CDCl}_{3}, 100 \mathrm{MHz}\right) \delta-2.0\left(\mathrm{~s}, \mathrm{ZnCH}_{2} \mathrm{CH}_{3}\right)$, 13.0(s, $\left.\mathrm{ZnCH}_{2} \mathrm{CH}_{3}\right), 52.7\left(\mathrm{~s}, \mathrm{CH}_{2}\right), 109.4,112.1,122.2,122.5$, 136.5, 137.9, 146.6, 147.1(CH-Py), 161.4, 165.3(two tert-C-Py). Anal. Calc. for $\mathrm{C}_{26} \mathrm{H}_{30} \mathrm{~N}_{6} \mathrm{Zn}_{2}$ : C, 56.03; H, 5.43; N, 15.08. Found: C, 56.43; H, 5.19; N, 15.12 .

\section{$\left(\mathrm{NPyC}_{2}^{\mathrm{NMe} 2}\right)_{2}(\mathrm{ZnEt})_{2}(2)$}

To a flask containing $\mathrm{HNPyC}_{2}^{\mathrm{NMe} 2}(0.58 \mathrm{~g}, 3.53 \mathrm{mmol})$ and $15 \mathrm{~mL}$ THF, $3.89 \mathrm{~mL} \mathrm{ZnEt}_{2}$ (1M in hexanes, $3.89 \mathrm{mmol}$ ) was added at $0^{\circ} \mathrm{C}$. The reaction mixture was allowed to warm to room temperature and reacted overnight. After $12 \mathrm{~h}$ of stirring, the yellow solution was pumped and then washed with hexane to afford a yellow solid. Yield $0.81 \mathrm{~g}, 89 \% .{ }^{1} \mathrm{H}$ NMR $\left(\mathrm{CDCl}_{3}, 400\right.$ MHz) $\delta 0.44\left(\mathrm{q}, \mathrm{ZnCH}_{2} \mathrm{CH}_{3}, J=7.6 \mathrm{~Hz}, 2 \mathrm{H}\right), 1.09\left(\mathrm{t}, \mathrm{ZnCH}_{2} \mathrm{CH}_{3}\right.$, $J=8 \mathrm{~Hz}, 3 \mathrm{H}), 2.09\left(\mathrm{~s}, \mathrm{~N}\left(\mathrm{CH}_{3}\right)_{2}, 6 \mathrm{H}\right), 2.48\left(\mathrm{t}, \mathrm{CH}_{2}, J=5.4 \mathrm{~Hz}\right.$, $2 \mathrm{H}), 3.26\left(\mathrm{br}, \mathrm{CH}_{2}, 2 \mathrm{H}\right), 6.22(\mathrm{t}, \mathrm{CH}-\mathrm{Py}, J=8.2 \mathrm{~Hz}, 1 \mathrm{H}), 6.45(\mathrm{~d}$, $\mathrm{CH}-\mathrm{Py}, J=8.8 \mathrm{~Hz}, 1 \mathrm{H}), 7.26(\mathrm{t}, \mathrm{CH}-\mathrm{Py}, J=7.8 \mathrm{~Hz}, 1 \mathrm{H}), 7.72(\mathrm{~d}$, $\mathrm{CH}-\mathrm{Py}, J=4.4 \mathrm{~Hz}, 1 \mathrm{H}) \cdot{ }^{13} \mathrm{C}\left\{{ }^{1} \mathrm{H}\right\} \mathrm{NMR}\left(\mathrm{CDCl}_{3}, 100 \mathrm{MHz}\right) \delta$ -2.5(s, $\left.\mathrm{ZnCH}_{2} \mathrm{CH}_{3}\right), 13.3\left(\mathrm{~s}, \mathrm{ZnCH}_{2} \mathrm{CH}_{3}\right), 43.8\left(\mathrm{~s}, \mathrm{CH}_{2}\right), 45.9$ (s, $\left.\mathrm{N}\left(\mathrm{CH}_{3}\right)_{2}\right), 61.0\left(\mathrm{~s}, \mathrm{CH}_{2}\right), 107.5,109.7,137.1,147.3$ (four $\mathrm{CH}-\mathrm{Py}$ ), 165.2(one tert-C-Py). Anal. Calc. for $\mathrm{C}_{22} \mathrm{H}_{38} \mathrm{~N}_{6} \mathrm{Zn}_{2}$ : C, 51.07; H, $7.40 ; \mathrm{N}, 16.24$. Found: C, 50.73; H, 7.50; N, 16.13 .

\section{$\mathrm{Zn}_{7} \mathrm{Et}_{6}(\mathrm{OBn})_{8}(4)$}

Mostly, zinc benzyl oxide complexes not only served as better nucleophilic reagents but also as more effective catalysts for ROP

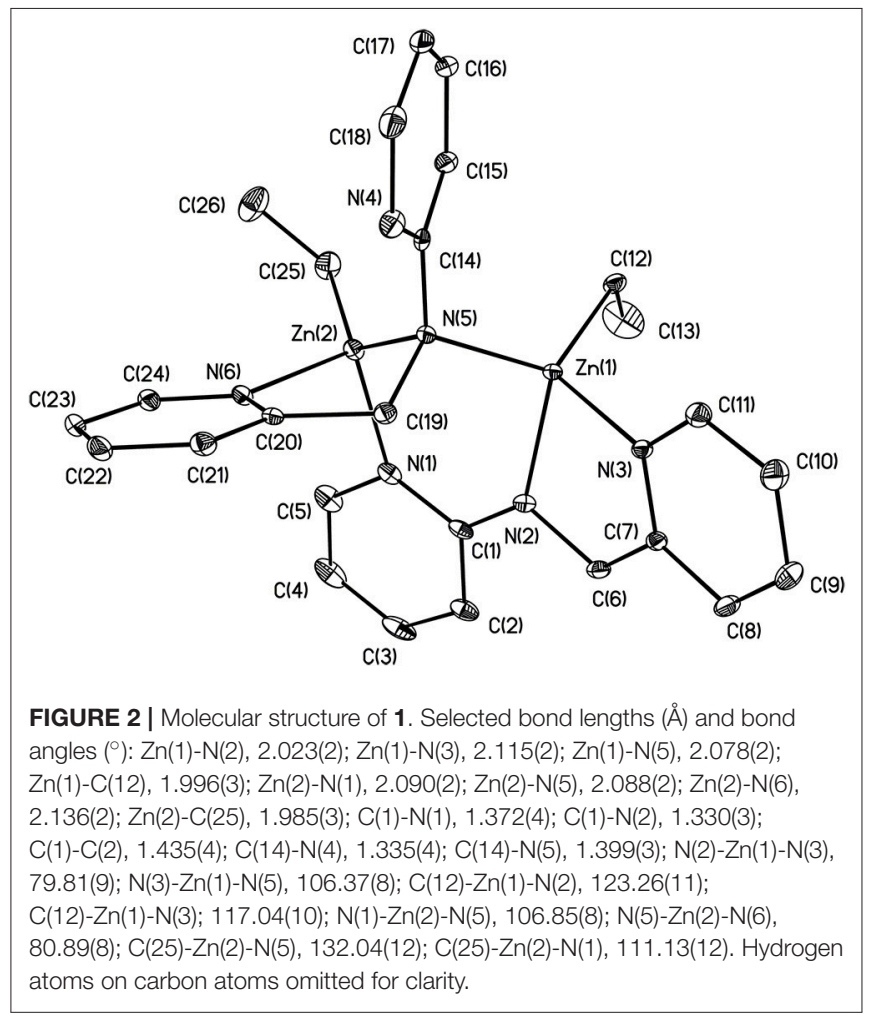

reaction than zinc alkyl complexes. In our case, synthesizing zinc benzyl oxide complexes via general routes was unsuccessful, as only the self-assembly bis(cubane) zinc benzyl oxide complex 
4 without the supporting ligand(s) was obtained. To a flask containing ligand precursors such as $\mathrm{HNPyC}_{1}^{\mathrm{Py}}$ or $\mathrm{HNPyC}_{2}^{\mathrm{NMe} 2}$ and $15 \mathrm{~mL}$ THF, 1 equivalent $\mathrm{ZnEt}_{2}$ (1M in hexanes) was

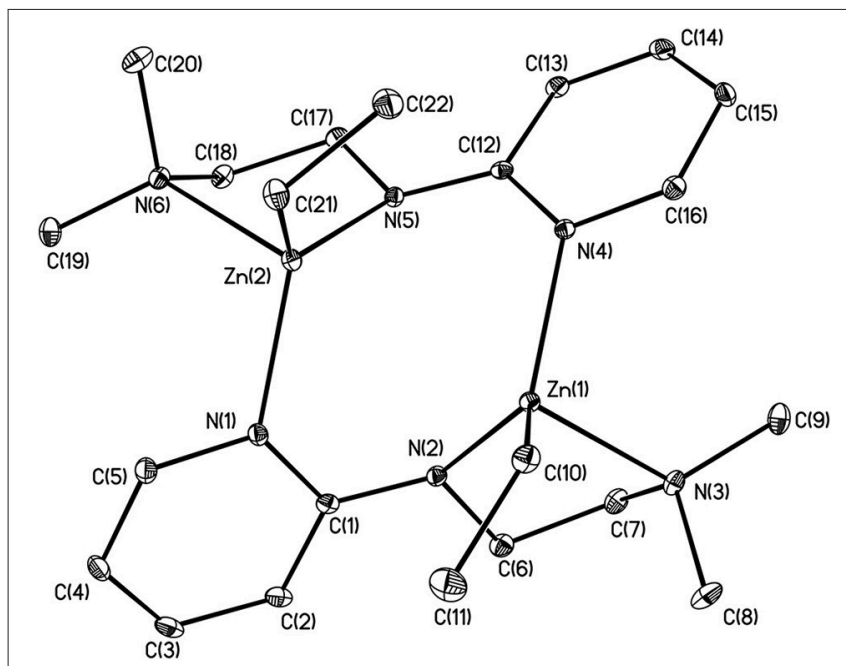

FIGURE 3 | Molecular structure of 2 . Selected bond lengths ( $(\AA)$ and bond angles $\left({ }^{\circ}\right)$ : Zn(1)-N(2), 2.0142(14); Zn(1)-N(3), 2.2424(14); Zn(1)-N(4), 2.0667(13); Zn(1)-C(10), 1.9915(16); Zn(2)-N(1), 2.0716(14); Zn(2)-N(5), 2.0133(13); Zn(2)-N(6), 2.2620(14); Zn(2)-C(21), 1.9928(17); C(1)-N(1), 1.370(2); C(1)-N(2), 1.339(2); C(1)-C(2), 1.430(2); C(12)-N(4), 1.372(2); $\mathrm{C}(12)-\mathrm{N}(5), 1.333(2) ; \mathrm{N}(2)-\mathrm{Zn}(1)-\mathrm{N}(4), 111.86(5) ; \mathrm{N}(3)-\mathrm{Zn}(1)-\mathrm{N}(4), 98.43(15) ;$ $\mathrm{C}(10)-\mathrm{Zn}(1)-\mathrm{N}(3), 112.07(6) ; \mathrm{C}(10)-\mathrm{Zn}(1)-\mathrm{N}(2) ; 122.67(6) ; \mathrm{N}(1)-\mathrm{Zn}(2)-\mathrm{N}(5), 11$ 1.20(5); N(5)-Zn(2)-N(6), 81.67(5); C(21)-Zn(2)-N(5), 125.07(6); $\mathrm{C}(21)-\mathrm{Zn}(2)-\mathrm{N}(1), 118.10(6)$. Hydrogen atoms on carbon atoms omitted for clarity. added at $0^{\circ} \mathrm{C}$. The reaction mixture was allowed to warm to room temperature and reacted for $3 \mathrm{~h}$. After $3 \mathrm{~h}$ of stirring, 1 equivalent benzyl alcohol was added and reacted for $3 \mathrm{~h}$. Volatile compounds were removed under vacuum to afford a yellow solid. A white crystalline solid complex $4\left(\mathrm{Zn}_{7} \mathrm{Et}_{6}(\mathrm{OBn})_{8}\right)$ and some unknown compounds were obtained after the crystallization process. For an alternative method, a flask containing benzyl alcohol $(0.71 \mathrm{~mL}, 6.84 \mathrm{mmol})$ and $15 \mathrm{~mL}$ hexane with $6 \mathrm{~mL}$ $\mathrm{ZnEt}_{2}(1 \mathrm{M}$ in hexanes, $6 \mathrm{mmol})$ was added at $0^{\circ} \mathrm{C}$. The reaction mixture was allowed to warm to room temperature and reacted for $3 \mathrm{~h}$. After filtration, a white solid was obtained. Yield $1.3 \mathrm{~g}$, 96\%. ${ }^{1} \mathrm{H} \mathrm{NMR}\left(\mathrm{CDCl}_{3}, 400 \mathrm{MHz}\right) \delta-0.32\left(\mathrm{~m}, \mathrm{ZnCH}_{2} \mathrm{CH}_{3}\right.$, $8 \mathrm{H}),-0.04\left(\mathrm{~m}, \mathrm{ZnCH}_{2} \mathrm{CH}_{3}, 4 \mathrm{H}\right), 0.72\left(\mathrm{~m}, \mathrm{ZnCH}_{2} \mathrm{CH}_{3}, 12 \mathrm{H}\right)$, 0.99(m, $\left.\mathrm{ZnCH}_{2} \mathrm{CH}_{3}, 6 \mathrm{H}\right), 4.76\left(\mathrm{~s}, \mathrm{CH}_{2} \mathrm{Ph}, 4 \mathrm{H}\right), 4.92\left(\mathrm{~s}, \mathrm{CH}_{2} \mathrm{Ph}\right.$, $4 \mathrm{H}), 5.04\left(\mathrm{~s}, \mathrm{CH}_{2} \mathrm{Ph}, 8 \mathrm{H}\right), 7.26$ (br s, $\left.\mathrm{CH}-\mathrm{Ph}, 3 \mathrm{H}\right), 7.38(\mathrm{~m}, \mathrm{CH}-\mathrm{Ph}$, $28 \mathrm{H}$ ), 7.49(br d, CH-Ph, $J=8.2 \mathrm{~Hz}, 9 \mathrm{H}) .{ }^{13} \mathrm{C}\left\{{ }^{1} \mathrm{H}\right\} \mathrm{NMR}\left(\mathrm{CDCl}_{3}\right.$, $100 \mathrm{MHz}) \delta-1.8\left(\mathrm{~s}, \mathrm{ZnCH}_{2} \mathrm{CH}_{3}\right), 0.1\left(\mathrm{~s}, \mathrm{ZnCH}_{2} \mathrm{CH}_{3}\right), 12.1(\mathrm{~s}$, $\mathrm{ZnCH}_{2} \mathrm{CH}_{3}$ ), $12.5\left(\mathrm{~s}, \mathrm{ZnCH}_{2} \mathrm{CH}_{3}\right), 69.0\left(\mathrm{~s}, \mathrm{OCH}_{2} \mathrm{Ph}\right), 70.1(\mathrm{~s}$, $\left.\mathrm{OCH}_{2} \mathrm{Ph}\right), 70.9\left(\mathrm{~s}, \mathrm{OCH}_{2} \mathrm{Ph}\right), 127.7(\mathrm{~s}, \mathrm{CH}-\mathrm{Ph}), 128.1(\mathrm{~d}, \mathrm{CH}-$ $\mathrm{Ph}$ ), 128.6(s, CH-Ph), 128.9(d, CH-Ph), 129.8(s, CH-Ph), 140.7, 141.5(two tert- $C-\mathrm{Ph}$ ). Anal. Calc. for $\mathrm{C}_{68} \mathrm{H}_{86} \mathrm{O}_{8} \mathrm{Zn}_{7}$ : C, 54.84; $\mathrm{H}$, 5.82. Found: C, 54.35; H, 5.25.

\section{X-Ray Data Collection and Structure Refinement}

Crystals 1-4 were grown from concentrated THF or hexane solution and isolated by filtration. The crystal was mounted onto a cryoloop and transferred into a cold nitrogen gas stream. Data were collected by a mounted Bruker AXS SMART 1000 diffractometer with graphite-monochromated Mo-K $\alpha$

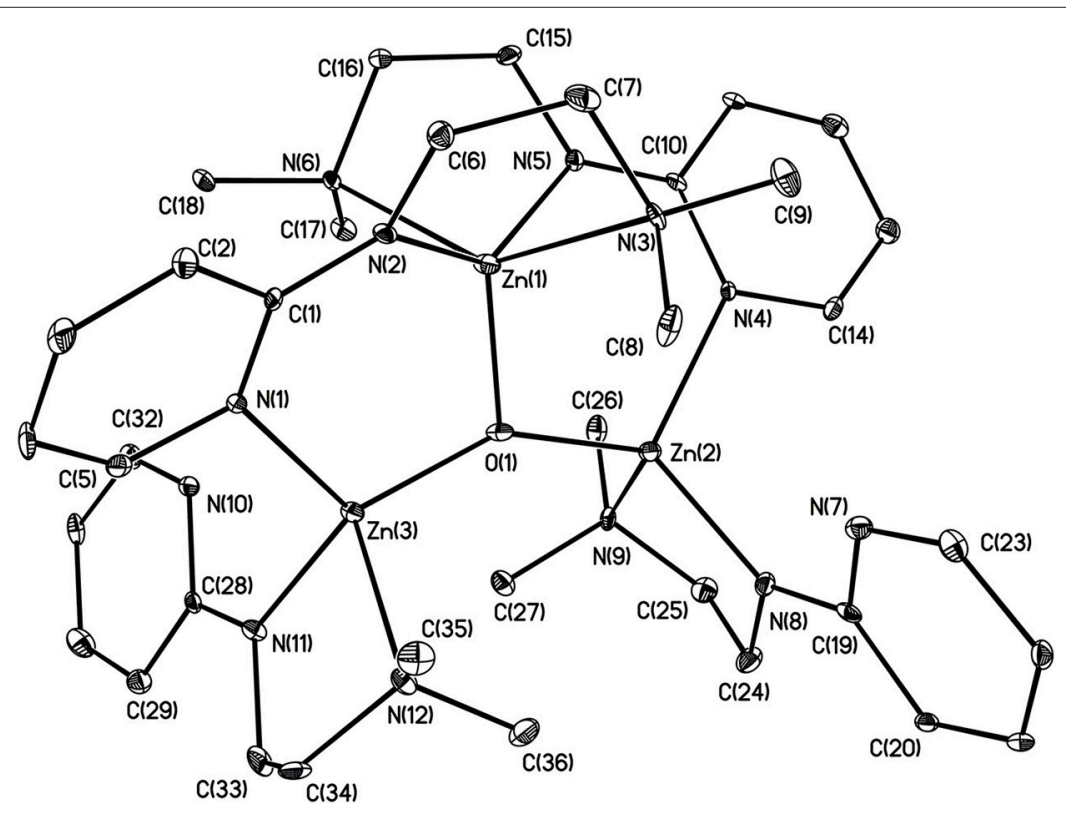

FIGURE 4 | Molecular structure of 3. Selected bond lengths (Å) and bond angles ( $\left.{ }^{\circ}\right)$ : Zn(1)-N(2), 1.998(3); Zn(1)-N(3), 2.458(3); Zn(1)-N(5), 2.001(3); Zn(1)-N(6), 2.397(3); Zn(1)-O(1), 1.833(2); Zn(2)-N(4), 2.070(3); Zn(2)-N(8), 1.956(3); Zn(2)-N(9), 2.192(3); Zn(2)-O(1), 1.864(2); Zn(3)-N(1), 2.087(3); Zn(3)-N(11), 1.935(3); $\mathrm{Zn}(3)-\mathrm{N}(12), 2.195(3) ; \mathrm{Zn}(3)-\mathrm{O}(1), 1.864(2) ; \mathrm{Zn}(1)-\mathrm{O}(1)-\mathrm{Zn}(2), 107.45(11) ; \mathrm{Zn}(1)-\mathrm{O}(1)-\mathrm{Zn}(3), 107.36(12) ; \mathrm{N}(3)-\mathrm{Zn}(1)-\mathrm{N}(2), 75.07(11) ; \mathrm{N}(5)-\mathrm{Zn}(1)-\mathrm{N}(6) ; 75.91(10) ;$ $\mathrm{N}(8)-Z n(2)-N(9), 82.87(12) ; \mathrm{N}(4)-Z n(2)-\mathrm{O}(1), 112.01(11) ; \mathrm{N}(1)-\mathrm{Zn}(3)-\mathrm{O}(1), 111.67(12) ; \mathrm{N}(11)-\mathrm{Zn}(3)-\mathrm{O}(1)$, 133.86(12). Hydrogen atoms on carbon atoms omitted for clarity. 
radiation $(\lambda=0.7107 \AA)$. Absorption correction was applied using SADABS (Sheldrick, 1996, 1997). Unit-cell parameter refinement, integration, and data reduction were carried out with the SAINT program (Brucker). The structure was solved by direct methods using a SHELXTL package (Spek, 2003, 2015; Sheldrick, 2015). All non-H atoms were located from successive Fourier maps, and hydrogen atoms were refined using a riding model. Anisotropic thermal parameters were used for all non-H atoms, and fixed isotropic parameters were used for $\mathrm{H}$ atoms.

CCDC 1863455-1863458 were contained in the Supplementary Material for this paper. The detailed crystal data can be obtained free of charge from The Cambridge Crystallographic Data Centre at the following web address: www. ccdc.cam.ac.uk/data_request/cif.

\section{General Procedure for the Ring Opening Polymerization Reaction}

To a flask containing the prescribed amount of monomer (Llactide or $\varepsilon$-caprolactone) and catalyst $(0.05 \mathrm{mmol}$ for L-lactide; $0.125 \mathrm{mmol}$ for $\varepsilon$-caprolactone), $10 \mathrm{~mL}$ (for L-lactide) or $15 \mathrm{~mL}$ (for $\varepsilon$-caprolactone) of solvent were added. The reaction mixture was stirred at the prescribed temperature for the prescribed time. After the reaction was quenched by the addition of $10 \mathrm{~mL}$ acetic acid solution $(0.35 \mathrm{~N})$, the resulting mixture was poured into $50 \mathrm{~mL} n$-heptane to precipitate polymers. Crude products were recrystallized from THF-hexane and dried in vacuo up to a constant weight.

\section{RESULTS AND DISCUSSION}

The ligand precursors $\mathrm{HNPyC}_{\mathrm{n}}^{\mathrm{E}}(n=1, \mathrm{E}=\mathrm{Py} ; n=2$, $\mathrm{E}=\mathrm{NMe}_{2}$ ) with aliphatic pendant functionalities were prepared from the copper(I)-catalyzed amination (Zhang et al., 2005) of 2-bromopyridine with suitable amines (2-aminomethyl pyridine for $\mathrm{HNPyC}_{1}^{\mathrm{Py}} ; N, N^{\prime}$-dimethylethylene diamine for $\mathrm{NHPyC}_{2}^{\mathrm{NMe} 2}$ ) containing CuI, $L$-proline and $\mathrm{K}_{3} \mathrm{PO}_{4}$ in DMSO at $110^{\circ} \mathrm{C}$ for $17 \mathrm{~h}$ to give moderate yields $\left(73 \%\right.$ for $\mathrm{HNPyC}_{1}^{\mathrm{Py}} ; 91 \%$ for $\mathrm{NHPyC}_{2}^{\mathrm{NMe} 2}$ ), following previously-established procedure (Chen et al., 2007, 2009; Chen and Chen, 2011). The ligand precursors, $\mathrm{HNPyC}_{\mathrm{n}}^{\mathrm{E}}$ are more easily synthesized by copper catalysis under air-controlled conditions than with other preparations (Foxon et al., 2002; Liu et al., 2007). In Figure 1, detailed synthetic routes and the depicted structures are introduced. In order to explore the potential catalytic properties of amidopyridinate zinc complexes, zinc complexes have been synthesized using $\mathrm{HNPyC}_{\mathrm{n}}^{\mathrm{E}}$ with $\mathrm{ZnEt}_{2}$ in a 1:1 molar ratio in THF or hexane isolating in the generation of zinc ethyl complexes 1-2. Complex 1 adopts mismatched coordination behavior in supporting the ligand, but complex 2 represents a centrosymmetric modular coordination system with the ligand. After purifying complex 2 with hexane, the filtrate is recrystallized to give zinc oxide complex 3. However, further data could not be obtained from the methodology suggested in the literature (Murso and Stalke, 2004), where the reaction was carried out by the treatment of ligand precursor $\mathrm{NHPyC}_{2}^{\mathrm{NMe} 2}$ with an equal equivalent of ${ }^{\mathrm{n}} \mathrm{BuLi}$ followed by the addition of $\mathrm{ZnCl}_{2}$. This was also true when an equivalent of water reacted with $\mathrm{ZnEt}_{2}$ and the ligand precursor also failed to get complex 3. In general, zinc benzyl oxide complexes exhibited better nucleophilic properties than zinc alkyl complexes, thus should be effective catalysts for ROP reaction (O'keefe et al., 2001). Attempts to synthesize zinc benzyl oxide complexes proven to be unsuccessful, with only the self-assembly bis(cubane) zinc benzyl oxide complex $\mathbf{4}$ without the supporting ligand(s) being obtained. Alternatively, complex 4 can also be introduced directly by using $\mathrm{ZnEt}_{2}$ with one equivalent benzyl alcohol in hexane. The spectroscopic analysis data of $\mathbf{1 - 2}$ and $\mathbf{4}$ correspond to the structures depicted in Figure 1. All of them are fully identified not only with NMR spectroscopy but also with elemental analyses.

X-ray structures 1-4 are determined and are obtained from concentrated hexane or concentrated THF solutions. All crystal structural images and data are summarized in Figures 2-5. The molecular structure of Complex 1 represents a noncentrosymmetric dimer formed by the association of two $\left[\mathrm{NPyC}_{1}^{\mathrm{Py}}\right]^{-}$moieties, which exhibit a 6-membered ring core motif as a distorted chair form (Figure 2). Two four-coordinate $\mathrm{Zn}$ atoms featuring the terminally $\mathrm{Zn}$-bound ethyl groups comprised complex $\mathbf{1}$. The geometry of zinc center $\mathbf{1}$ can be seen as a distorted tetrahedral geometry and uses one amido nitrogen atom $\mathrm{N}(5)$ to bridge two zinc centers. This coordination behavior

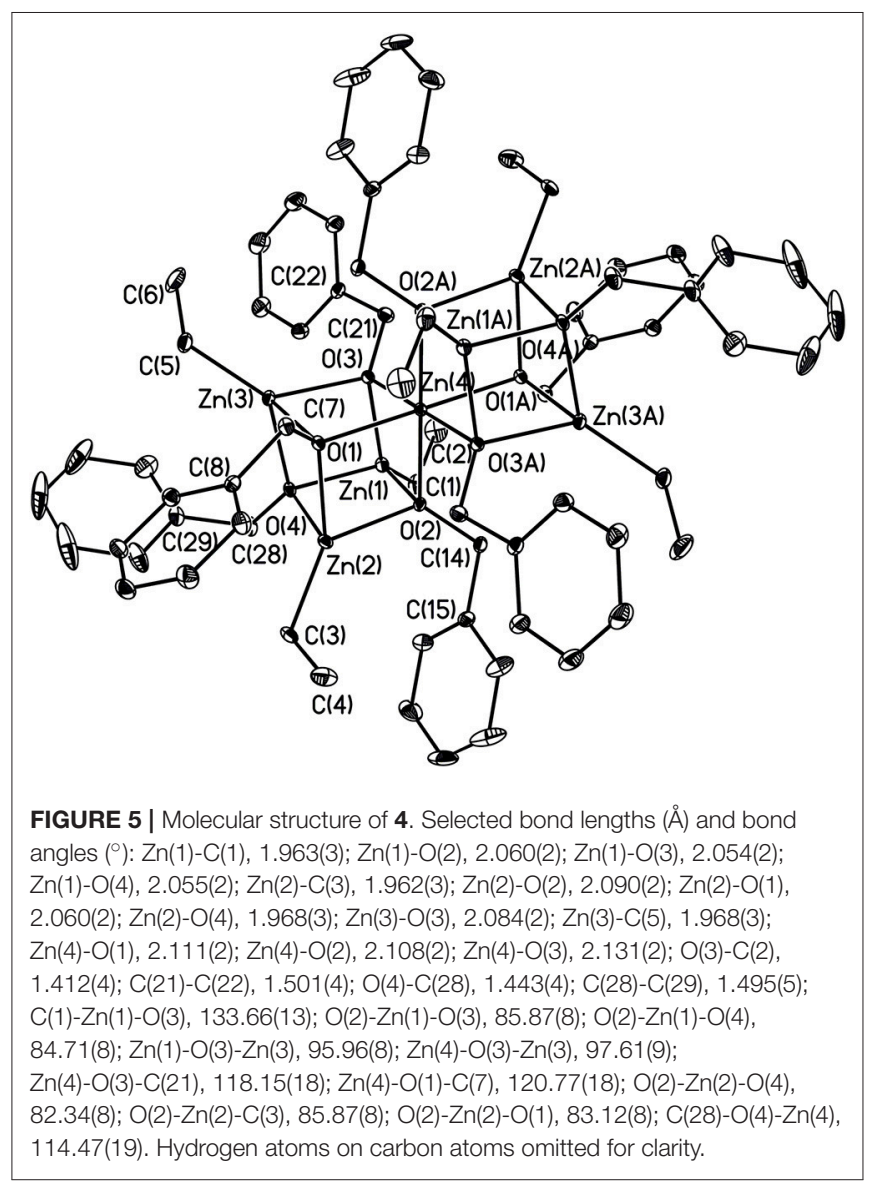


TABLE 1 | Polymerization of L-Lactide and $\varepsilon$-caprolactone using complexes $\mathbf{1 - 2 , 4}$ at $50^{\circ} \mathrm{C}^{\mathrm{a}}$.

\begin{tabular}{|c|c|c|c|c|c|c|c|c|c|c|}
\hline Entry & Monomer & Solvent & Cat. & $\left\{[\mathrm{M}]_{0}:[\mathrm{Zn}]_{0}\right\}:[\mathrm{BnOH}]$ & Time (min) & $M_{n}(o b s d)^{b}$ & $\underset{(c a l c d)^{c}}{M_{n}}$ & Conv. $(\%)^{d}$ & Yield (\%) & $M_{w} / M_{n}^{b}$ \\
\hline 1 & & Toluene & 1 & $50: 1$ & 15 & $10,600(6,200)$ & 6,900 & 94 & 79 & 1.16 \\
\hline 2 & & Toluene & 2 & $50: 1$ & 15 & $11,800(6,800)$ & 6,900 & 94 & 75 & 1.07 \\
\hline 3 & & Toluene & 4 & $50: 1$ & 120 & - & - & 15 & - & - \\
\hline 4 & & Toluene & 4 & $50: 1$ & 1,440 & $21,000(12,200)$ & 7,200 & 98 & 82 & 1.38 \\
\hline 5 & & Toluene & 1 & $200: 1$ & 45 & $40,300(23,400)$ & 28,400 & 98 & 86 & 1.35 \\
\hline 6 & & Toluene & 1 & $300: 1$ & 50 & $27,700(16,100)$ & 42,100 & 97 & 88 & 2.20 \\
\hline 7 & & Toluene & 2 & $100: 1$ & 15 & $28,000(16,200)$ & 13,500 & 93 & 82 & 1.05 \\
\hline 8 & & Toluene & 2 & $150: 1$ & 30 & $34,100(19,800)$ & 18,900 & 87 & 73 & 1.09 \\
\hline 9 & & Toluene & 2 & $200: 1$ & 45 & $46,200(26,800)$ & 27,200 & 94 & 84 & 1.21 \\
\hline 10 & & Toluene & 2 & $300: 1$ & 50 & $38,200(22,200)$ & 41,600 & 96 & 83 & 1.35 \\
\hline $11^{f}$ & & THF & 2 & $50: 1$ & 120 & $6,600(3,700)$ & 5,200 & 90 & 78 & 1.21 \\
\hline $12^{f}$ & & $\mathrm{DCM}$ & 2 & $50: 1$ & 120 & - & - & Trace & - & - \\
\hline $13^{f}$ & & Toluene & 2 & $50: 1$ & 120 & $15,100(8,500)$ & 5,800 & 99 & 80 & 1.22 \\
\hline $14^{f}$ & & THF & 1 & $50: 1$ & 120 & - & - & 62 & - & - \\
\hline $15^{f}$ & & DCM & 1 & $50: 1$ & 120 & - & - & 13 & - & - \\
\hline $16^{f}$ & & Toluene & 1 & $50: 1$ & 120 & $14,100(7,900)$ & 5,500 & 95 & 80 & 1.35 \\
\hline $17^{f}$ & & THF & 4 & $50: 1$ & 120 & - & - & 60 & - & - \\
\hline $18^{f}$ & & DCM & 4 & $50: 1$ & 120 & - & - & 27 & - & - \\
\hline $19^{f}$ & & Toluene & 4 & $50: 1$ & 120 & $10,300(5,800)$ & 4,400 & 75 & - & 1.12 \\
\hline 20 & & Toluene & 1 & $50: 1$ & 8 & $11,100(6,200)$ & 4,900 & 84 & 72 & 1.14 \\
\hline 21 & & Toluene & 2 & $50: 1$ & 8 & $11,200(6,300)$ & 5,600 & 97 & 83 & 1.08 \\
\hline 22 & & Toluene & 4 & $50: 1$ & 60 & $4,900(2,700)$ & 5,800 & 99 & 78 & 1.16 \\
\hline 23 & & Toluene & 2 & $100: 1$ & 15 & $21,800(12,200)$ & 11,000 & 95 & 82 & 1.11 \\
\hline 24 & & Toluene & 2 & $150: 1$ & 20 & $32,300(18,100)$ & 16,900 & 98 & 87 & 1.27 \\
\hline
\end{tabular}

a For L-Lactide: $10 \mathrm{~mL}$ solvent, $[\mathrm{Zn}]_{0}=0.005 \mathrm{M},[\mathrm{BnOH}]=0.005 \mathrm{M}$; for $\varepsilon$-caprolactone: $15 \mathrm{~mL}$ solvent. $[\mathrm{Zn}]_{0}=8.33 \mathrm{mM} ;[\mathrm{BnOH}]=8.33 \mathrm{mM}$.

${ }^{b}$ Obtained from GPC analysis and calibrated by polystyrene standard. Values in parentheses are the values obtained from GPC times 0.58 for PLA; 0.56 for PCL.

${ }^{c}$ Calculated from $\left[\mathrm{Mw}(\right.$ monomer $) \times[\mathrm{M}]_{0} /[\mathrm{Zn}]_{0} \times$ conversion $\left./\left([\mathrm{BnOH}]_{(\mathrm{eq})}\right]+\mathrm{M}(\mathrm{BnOH})\right)$.

${ }^{\mathrm{O} O b t a i n e d}$ from ${ }^{1} \mathrm{H}$ NMR analysis.

e/solated yield.

${ }^{f} T=26^{\circ} \mathrm{C}$.

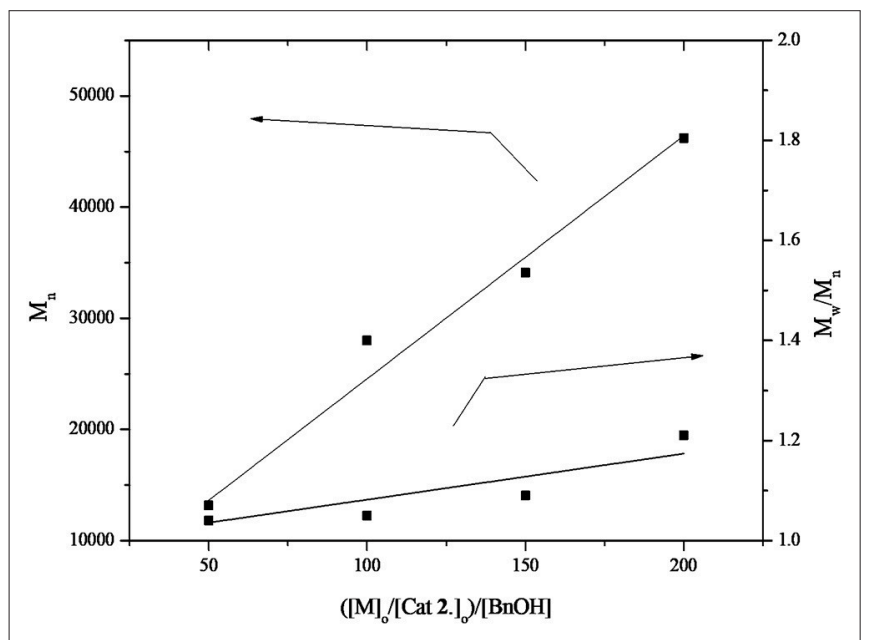

FIGURE 6 | Polymerization of L-lactide catalyzed by 2 in toluene at $50^{\circ} \mathrm{C}$.

is limited and not easily found in the literature. Each zinc atom is four-coordinate, which exhibited the bonding mode comprising one nitrogen atom of the pyridyl groups with $\mathrm{Zn}(1)-\mathrm{N}(3)$,
$\mathrm{Zn}(2)-\mathrm{N}(1), \mathrm{Zn}(2)-\mathrm{N}(6)$ bond distances of 2.115(2), 2.090(2), $2.136(2) \AA$ and one nitrogen atom of the amido groups with $\mathrm{Zn}(1)-\mathrm{N}(2), \mathrm{Zn}(1)-\mathrm{N}(5), \mathrm{Zn}(2)-\mathrm{N}(5)$ bond distances of 2.023(2), 2.078(2), 2.088(2) ̊. Complex 2 exists as a centrosymmetric dimer and shows as an 8-membered ring core motif which is similar to zinc pyridyl systems (Zheng et al., 2008). The zinc centers have a distorted tetrahedral geometry. The metal centers of the zinc atoms are four-coordinate, which demonstrated the bonding mode, including one nitrogen atom of the amine groups with $\mathrm{Zn}(1)-\mathrm{N}(3), \mathrm{Zn}(2)-\mathrm{N}(6)$ bond distances of 2.2424(14), 2.2620(14) $\AA$, one nitrogen atom of the amido groups with $\mathrm{Zn}(1)-$ $\mathrm{N}(2), \mathrm{Zn}(2)-\mathrm{N}(5)$ bond distance of 2.0142(14), 2.0133(13) , and one nitrogen atom of the pyridyl groups with $\mathrm{Zn}(1)-\mathrm{N}(4)$, $\mathrm{Zn}(2)-\mathrm{N}(1)$ bond distance of 2.0677(13), 2.0716(14) $\mathrm{A}$. The solid state structure of $\mathbf{3}$ is comprised of three zinc cations, a single oxygen $\mathrm{O}^{2-}$-dianion and four monoanionic ligand fragments as shown in Figure 4. Two metal centers, $\mathrm{Zn}(2)$ and $\mathrm{Zn}(3)$, have a distorted tetrahedral geometry with one $\mu_{3}-\mathrm{O}$ atom and two nitrogen atoms. The other metal center $[\mathrm{Zn}(1)]$ shows a distorted square pyramidal geometry with one $\mu_{3}-\mathrm{O}$ atom and four nitrogen atoms. In complex 3 , the $\mathrm{Zn}-\mathrm{O}$ bond distances are $1.883(3), 1.866(2)$ and 1.863(2) ̊ showing two different bonding 
lengths. Two different coordinate modes are demonstrated by four ligands, one type being the uncoordinated pyridyl group, and this could be caused by the balance and bond distances (Murso and Stalke, 2004). Figure 5 shows the solid state plot of 4. There are two shared $\mathrm{Zn}-\mathrm{O}$ cubes in this molecule. Two bonding modes for zinc centers in complex 4, and six of the $\mathrm{Zn}$ atoms, are $T_{d}$ geometry with the shared $\mathrm{Zn}$ adopting an $\mathrm{O}_{h}$ geometry. Adopting with four $\mu_{3}-\mathrm{O}_{\text {benzyl }}$ and three terminal ethyl groups fills the metal center geometry (for each individual cubane); for the Td bonding mode of $\mathrm{Zn}$ atoms three $\mu 3$ Obenzyl groups are used, whereas for the Oh-bound $\mathrm{Zn}$ atoms six $\mu 3$-Obenzyl groups are used. The $\mathrm{Zn}-\mathrm{O}$ bonds to the central $\mathrm{Zn}(1)$ atom are approximately $0.077 \AA$ longer than those to the other $\mathrm{Zn}$ atoms. The bonding angles of $\mathrm{Zn}-\mathrm{O}-\mathrm{Zn}$ are generally larger $\left[94.90(8)-97.69(9)^{\circ}\right]$ than the bonding angles of O-Zn-O $\left[81.47(8)-83.91(6)^{\circ}\right]$; the angles are within one cube and akin to the reported literature (Ishimori et al., 1976; Lewinski et al., 2003, 2008; Boyle et al., 2004; Jana et al., 2007; Tsaroucha et al., 2011; Prochowicz et al., 2014).

Undoubtedly, BDI zinc complexes are very active catalytic species/systems in ring opening polymerization (ROP), but to our best knowledge, amidopyridinate complexes provide limited information toward this aspect. Based on the previous work on anilido-pyridinate zinc system for ROP (Chen and Chen, 2017), the optimized solvent/temperature combination is revealed to be $10 \mathrm{~mL}$ toluene at $50^{\circ} \mathrm{C}$, using benzyl alcohol as the transfer/initiation reagent after several trials on polymerization with $\mathrm{CH}_{2} \mathrm{Cl}_{2}$, THF and toluene. The same conditions were used to check the activities of the three catalysts 1, 2, and 4 . Polymerization of L-lactide, carried out by applying complexes $\mathbf{1}, \mathbf{2}$, and $\mathbf{4}$ as catalysts by using benzyl alcohol as the initiation reagent, has been methodically studied and operated under a dry nitrogen atmosphere. In Table 1, representative data are summarized and listed. Notably, experimental results show that complexes $\mathbf{1}$ and $\mathbf{2}$ demonstrate more positive activities than 4 within the same period (entries 1-3), whereas 4 exhibits an inferior conversion at $50^{\circ} \mathrm{C}$ up to $120 \mathrm{~min}$ (entry 3). But when loading the high ratios of monomer at $50^{\circ} \mathrm{C}$ (entry 6), poor PDI is demonstrated by complex $\mathbf{1}$, with the reasonable assumption that this is caused by the interactions between pendant functionality of ligand precursors, the metal center and the rigidity of pyridyl group, which impedes the attraction of benzyl alcohol or monomer to the metal center, resulting in a hinderance of the propagation process in the polymerization. Referred to the same monomer loading, complex 2 shows a more controlled manner (entry 10). In addition, the kinetic studies

\section{0 eq. PLA}

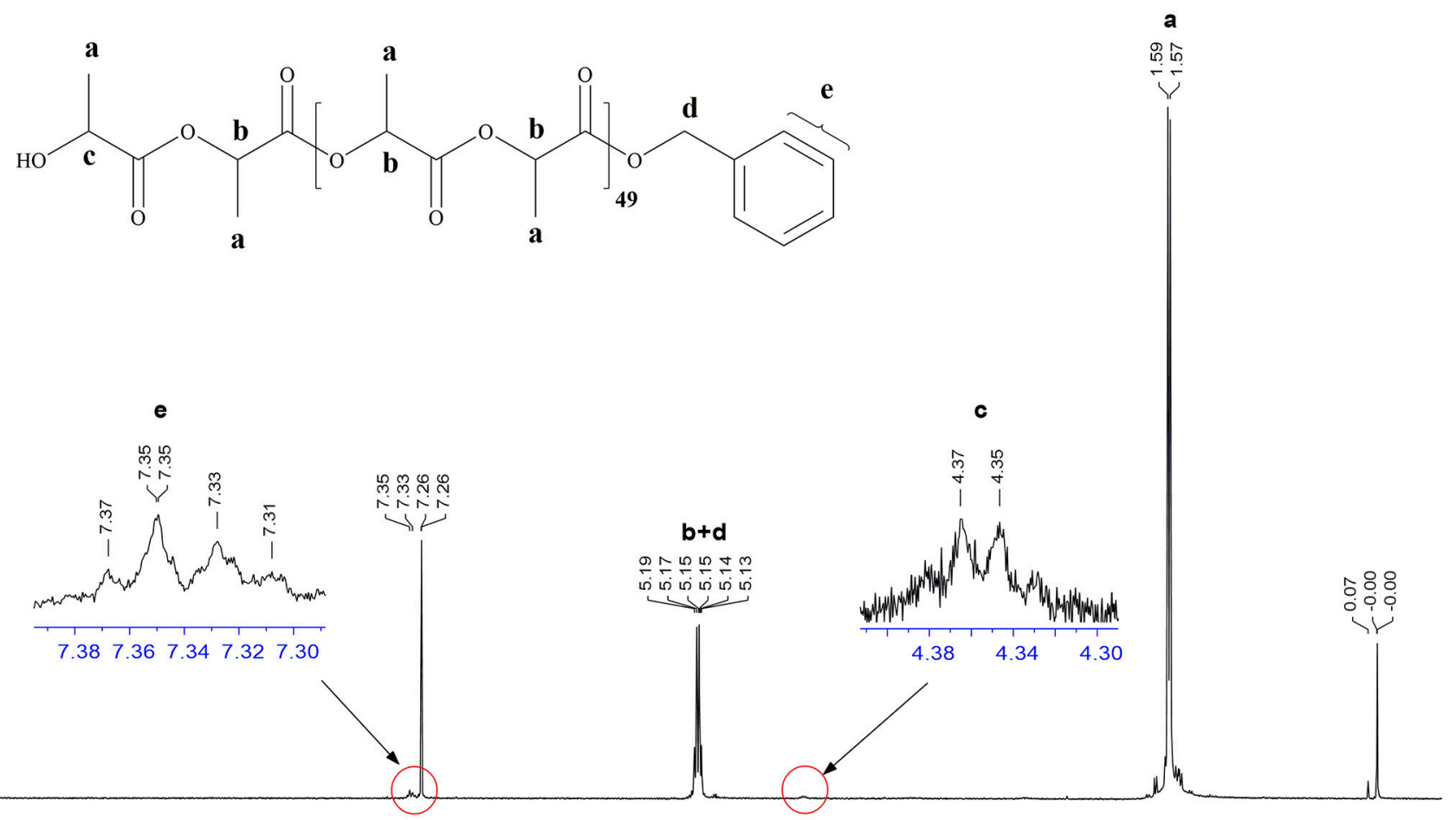


of complexes $\mathbf{1}$ and $\mathbf{2}$ for polymerization L-lactide were carried out with benzyl alcohol, and complex 1 held better activities than did complex 2 (see Supplementary Material). Because of the easy preparation and manipulable attributes, complex 2 was utilized for investigation in the presence of optimized conditions. The linear relationship between the number-average molecular weight $\left(\mathrm{M}_{\mathrm{n}}\right)$ and the monomer-to-initiator ratio $\left([\mathrm{M}]_{0} /[\mathrm{I}]_{0}\right)$ demonstrated in Figure 6 (entries 2, 7-10) implies the "living" character of the polymerization process. Analysis of the produced polymer end group is testified by the ${ }^{1} \mathrm{H}$ NMR spectrum and the polymer sample is obtained from Llactide and $2\left([\mathrm{M}]_{0} /[\mathrm{BnOH}]=50\right)$. All peaks are assignable and corresponded to the proposed structure capped with the benzyl alkoxyl group, as shown in Figure 7. This indicates the $\mathrm{Zn}$ complex/BnOH catalytic behavior might follow the pathway as an "activated monomer," where it or $\mathrm{BnOH}$ are activated by complex 2 and $\mathrm{BnOH}$ plays as a nucleophilic role (Huang et al., 2008; Romain et al., 2017). Both complexes 1 and 2 show similar activities, but complex 2 with $\mathrm{NMe}_{2}$ substituted with functional group ligands exhibits more controllable behavior for polymerization. Complexes 1, 2, and 4 were also studied to demonstrate their catalytic behavior in the ROP of $\varepsilon$-caprolactone (CL). Representative results are also summarized in Table 1 (entries 11-24). Selected experimental results indicate that complex $\mathbf{2}$ has a more easily controlled disposition for catalyzing ROP of CL compared to complexes 1 and 4 (entries 11-19). Complex 4 demonstrates improved activity for polymerization of CL compared to L-lactide (entry 22 vs. 3). The resulting polymers of PCLs give reasonable number-average molecular weight $\left(\mathrm{M}_{n}\right)$ and poly dispersity index (PDI) values (1.08-1.27). The relationship of $\mathrm{M}_{\mathrm{n}}$ vs. $\left([\mathrm{M}]_{0} /[\mathrm{I}]_{0}\right)$ is illustrated by the data conducted by complex 2 ; it possesses a roughly linear relationship and carries out polymerization in a controlled manner. The ${ }^{1} \mathrm{H}$ NMR analysis of the end group is also carried out and the result is similar to PLA (Figure 8). This result means that polymerization of $\varepsilon$-caprolactone followed the same catalytic behavior with L-lactide. Depending on catalytic results, we can conclude complexes $\mathbf{1}$ and $\mathbf{2}$ should proceed via a different pathway in the ROP reaction compared to complex 4 .

\section{CONCLUSIONS}

We have reported the preparation and full characterizations of new amidopyridinate zinc complexes. Two coordinate modes of zinc ethyl complexes supported with amidopyridinate ligands and one self-assembly zinc benzyl oxide cubane complex were created and investigated. Under optimized conditions,

50 eq. PCL

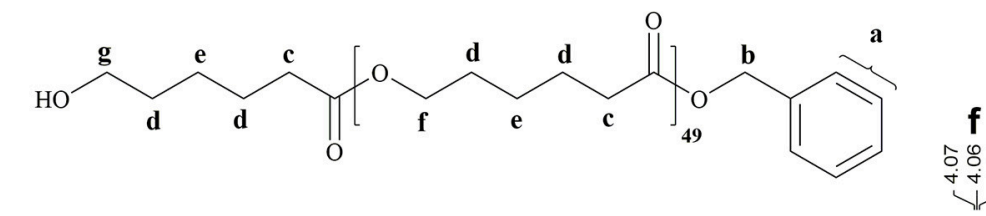

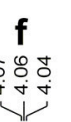
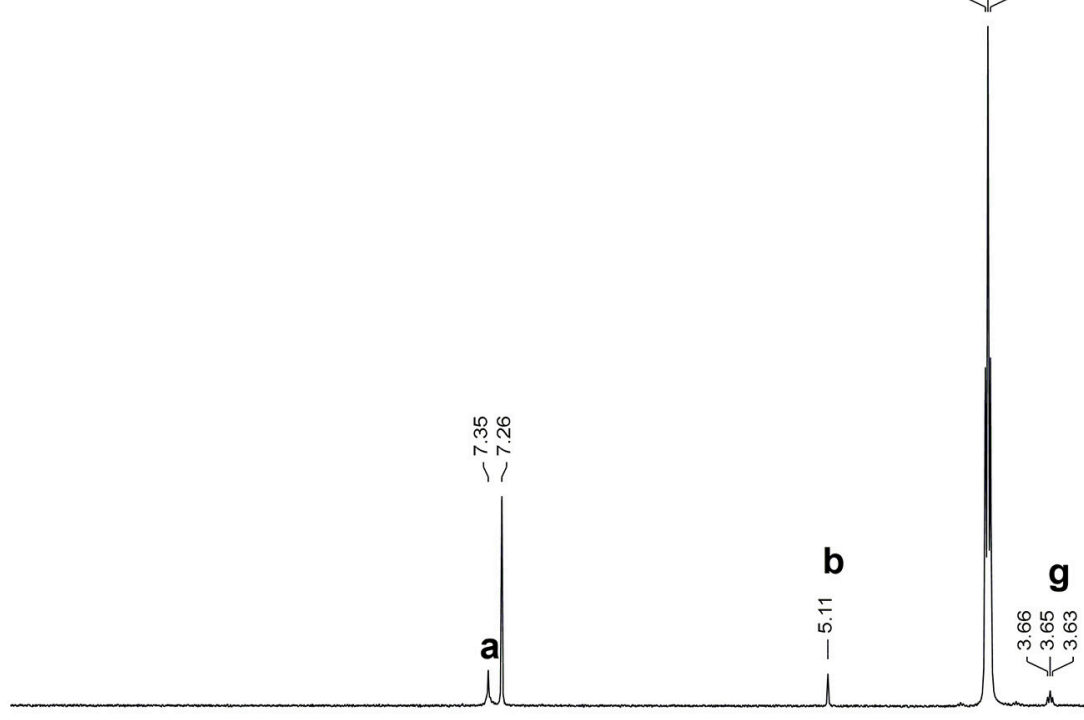

C

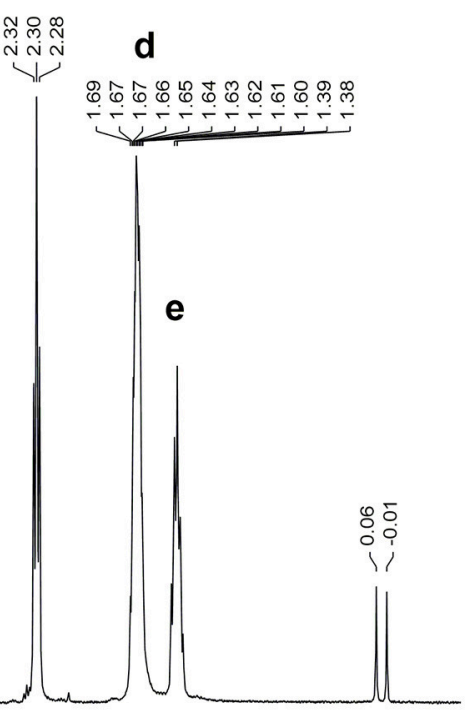

10

9

8

7

6

f1 (ppm)

5

4

3

3

2

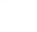

FIGURE 8 | ${ }^{1} \mathrm{H}$ NMR spectrum of PCL-50 catalyzed by 2 in toluene at $50^{\circ} \mathrm{C}$. 
amidopyridinate zinc complexes demonstrate efficient activities for the ring opening polymerization of L-lactide and $\varepsilon$ caprolactone when employing benzyl alcohol as the initiation reagent. Initial studies are focusing on advancing the finetuning of ligand precursors and more advanced research will pay more attention to applying metal complexes for the undergoing catalytic reactions.

\section{AUTHOR CONTRIBUTIONS}

All authors listed have made a substantial, direct and intellectual contribution to the work, and approved it for publication.

\section{REFERENCES}

Alaaeddine, A., Amgoune, A., Thomas, C. M., Dagorne, S., Bellemin-Laponnaz, S., and Carpentier, J.-F. (2006). Bis[bis(oxazolinato)] complexes of yttrium and lanthanum: Molecular structure and use in polymerization of dllactide and dl- $\beta$-butyrolactone. Eur. J. Inorg. Chem. 2006, 3652-3658. doi: 10.1002/ejic.200600437

Boyle, T. J., Bunge, S. D., Andrews, N. L., Matzen, L. E., Sieg, K., Rodriguez, M. A., et al. (2004). Precursor structural influences on the final zno nanoparticle morphology from a novel family of structurally characterized zinc alkoxy alkyl precursors. Chem. Mater. 16, 3279-3288. doi: 10.1021/cm0493997

Chen, C.-T., Liao, C.-H., Peng, K.-F., Chen, M.-T., and Huang, T.-L. (2014), Synthesis, characterization and catalytic studies of aluminium complexes containing sulfonamido-oxazolinate or -pyrazolinate ligands. J. Organomet. Chem. 753, 9-19. doi: 10.1016/j.jorganchem.2013.12.022

Chen, C. T., Chan, C. Y., Huang, C. A., Chen, M. T., and Peng, K. F. (2007). Zinc anilido-oxazolinate complexes as initiators for ring opening polymerization. Dalton Trans. 4073-4078. doi: 10.1039/b705398c

Chen, M.-T., and Chen, C.-T. (2017). An unprecedented zn10o4 heteroadamantane cage containing anilido-pyridinate ligand and its activity for ring opening polymerization of l-lactide and $\varepsilon$-caprolactone. Dalton Trans. 46, 10181-10184. doi: 10.1039/C7DT01925D

Chen, M. T., Chang, P. J., Huang, C. A., Peng, K. F., and Chen, C. T. (2009). Magnesium complexes containing bis-amido-oxazolinate ligands as efficient catalysts for ring opening polymerisation of l-lactide. Dalton Trans. 9068-9074. doi: 10.1039/b907549f

Chen, M. T., and Chen, C. T. (2011). Structural and catalytic studies of zinc complexes containing amido-oxazolinate ligands. Dalton Trans. 40, 12886-12894. doi: 10.1039/c1dt10974j

Cheng, M., Attygalle, A. B., Lobkovsky, E. B., and Coates, G. W. (1999). Single-site catalysts for ring-opening polymerization: Synthesis of heterotactic poly(lactic acid) from rac-lactide. J. Am. Chem. Soc. 121, 11583-11584. doi: $10.1021 /$ ja992678o

Cheng, M., Darling, N. A., Lobkovsky, E. B., and Coates, G. W. (2000). Enantiomerically-enriched organic reagents polymer synthesis: enantioselective copolymerization of cycloalkene oxides and co using homogeneous, zinc-based catalysts. Chem. Commun. 2007-2008. doi: 10.1039/b005537i

Chisholm, M. H., and Zhou, Z. (2004). New generation polymers: the role of metal alkoxides as catalysts in the production of polyoxygenates. J. Mater. Chem. 14, 3081-3092. doi: 10.1039/b405489j

Coates, G. W. (2002). Polymerization catalysis at the millennium: Frontiers in stereoselective, metal-catalyzed polymerization. J. Chem. Soc. Dalton Trans. 467-475. doi: 10.1039/b111226k

Coates, G. W., and Moore, D. R. (2004). Discrete metal-based catalysts for the copolymerization of $\mathrm{CO} 2$ and epoxides: Discovery, reactivity, optimization, and mechanism. Angew. Chem. Int. Ed. 43, 6618-6639. doi: 10.1002/anie.200460442

Foxon, S., Walter, O., and Schindler, S. (2002). Syntheses and characterization of copper(ii) complexes of the new

\section{ACKNOWLEDGMENTS}

We are grateful to the Ministry of Science and Technology of Taiwan for financial support (grant numbers MOST 106-2113M-126-001-MY2, MOST 107-2113-M-126-001-MY2, and MOST 106-2113-M-005-016).

\section{SUPPLEMENTARY MATERIAL}

The Supplementary Material for this article can be found online at: https://www.frontiersin.org/articles/10.3389/fchem. 2018.00615/full\#supplementary-material

ligands $\mathrm{n}$-[(2-pyridyl)methyl]-2,2'-dipyridylamine and $\mathrm{n}$-[bis(2pyridyl)methyl]-2-pyridylamine. Eur. J. Inorg. Chem. 2002, 111-121. doi: 10.1002/1099-0682(20021)2002:1 < 111::AID-EJIC111>3.0.CO;2-7

Gamer, M. T., Rastätter, M., Roesky, P. W., Steffens, A., and Glanz, M. (2005). Yttrium and lanthanide complexes with various $\mathrm{p}, \mathrm{n}$ ligands in the coordination sphere: synthesis, structure, and polymerization studies. Chem. Eur. J. 11, 3165-3172. doi: 10.1002/chem.200401062

Gogate, P. N., Ethirajan, M., Kurenova, E. V., Magis, A. T., Pandey, R. K., and Cance, W. G. (2014). Design, synthesis, and biological evaluation of novel fak scaffold inhibitors targeting the fak-vegfr3 protein-protein interaction. Eur. J. Med. Chem. 80, 154-166. doi: 10.1016/j.ejmech.2014.04.041

Gong, S., and Ma, H. (2008). $\beta$-diketiminate aluminium complexes: Synthesis, characterization and ring-opening polymerization of cyclic esters. Dalton Trans. 3345-3357. doi: 10.1039/b802638f

Hill, M. S., and Hitchcock, P. B. (2002). Synthesis of c2 and cs symmetric zinc complexes supported by bis(phosphinimino)methyl ligands and their use in ring opening polymerisation catalysis. J. Chem. Soc. Dalton Trans. 4694-4702. doi: $10.1039 / \mathrm{b} 207358 \mathrm{~g}$

Huang, C.-A., Ho, C.-L., and Chen, C.-T. (2008). Structural and catalytic studies of lithium complexes bearing pendant aminophenolate ligands. Dalton Trans. 3502-3510. doi: 10.1039/b717370a

Ishimori, M., Hagiwara, T., Tsuruta, T., Kai, Y., Yasuoka, N., and Kasai, N. (1976). The structure and reactivity of [zn(ome)2(etznome)6]. Bull. Chem. Soc. Jpn. 49, 1165-1166. doi: 10.1246/bcsj.49.1165

Jana, S., Berger, R. J. F., Fröhlich, R., Pape, T., and Mitzel, N. W. (2007). Oxygenation of simple zinc alkyls: surprising dependence of product distributions on the alkyl substituents and the presence of water. Inorg. Chem. 46, 4293-4297. doi: 10.1021/ic062438r

Kröger, M., Folli, C., Walter, O., and Döring, M. (2005). Alternating copolymerization of cyclohexene oxide and $\mathrm{co} 2$ catalyzed by zinc complexes with new 3-amino-2-cyanoimidoacrylate ligands. Adv. Synth. Catal. 347, 1325-1328. doi: 10.1002/adsc.200505113

Kröger, M., Folli, C., Walter, O., and Döring, M. (2006). A new amidoimidomalonate zinc complex with a sedecameric solid state structure catalyzing the copolymerization of $\mathrm{co} 2$ and cyclohexene oxide. J. Organomet. Chem. 691, 3397-3402. doi: 10.1016/j.jorganchem.2006.04.018

Lee, B. Y., Kwon, H. Y., Lee, S. Y., Na, S. J., Han, S.-I., Yun, H., et al. (2005). Bimetallic anilido-aldimine zinc complexes for epoxide/co2 copolymerization. J. Am. Chem. Soc. 127, 3031-3037. doi: 10.1021/ja0435135

Lewinski, J., Marciniak, W., Lipkowski, J., and Justyniak, I. (2003). New insights into the reaction of zinc alkyls with dioxygen. J. Am. Chem. Soc. 125, 12698-12699. doi: 10.1021/ja036020t

Lewinski, J., Suwała, K., Kubisiak, M., Ochal, Z., Justyniak, I., and Lipkowski, J. (2008). Oxygenation of a me $2 \mathrm{zn} / \alpha$-diimine system: a unique zinc methylperoxide cluster and evidence for its sequential decomposition pathways. Angew. Chem. Int. Ed. 47, 7888-7891. doi: 10.1002/anie.200803254

Liu, B., Cui, D., Ma, J., Chen, X., and Jing, X. (2007). Synthesis and reactivity of rare earth metal alkyl complexes stabilized by anilido phosphinimine and amino phosphine ligands. Chem. Eur. J. 13, 834-845. doi: 10.1002/chem.200601125 
Murso, A., and Stalke, D. (2004). Electronic response of a (p,n)-based ligand on metal coordination. Dalton Trans. 2563-2569. doi: 10.1039/B405680A

Nakano, K., Kosaka, N., Hiyama, T., and Nozaki, K. (2003). Metal-catalyzed synthesis of stereoregular polyketones, polyesters, and polycarbonates. Dalton Trans. 4039-4050. doi: 10.1039/B304690G

O'keefe, B. J., Hillmyer, M. A., and Tolman, W. B. (2001). Polymerization of lactide and related cyclic esters by discrete metal complexes. J. Chem. Soc. Dalton Trans. 2215-2224. doi: 10.1039/b104197p

Peng, K.-F., and Chen, C.-T. (2009). Synthesis and catalytic application of aluminium anilido-pyrazolate complexes. Dalton Trans. 9800-9806. doi: 10.1039/b905394h

Peng, K.-F., Chen, Y., and Chen, C.-T. (2015). Synthesis and catalytic application of magnesium complexes bearing pendant indolyl ligands. Dalton Trans. 44, 9610-9619. doi: 10.1039/C5DT01173F

Prochowicz, D., Sokołowski, K., and Lewinski, J. (2014). Zinc hydroxides and oxides supported by organic ligands: synthesis and structural diversity. Coord. Chem. Rev. 270-271, 112-126. doi: 10.1016/j.ccr.2013.12.003

Puelacher, W. C., Mooney, D., Langer, R., Upton, J., Vacanti, J. P., and Vacanti, C. A. (1994). Design of nasoseptal cartilage replacements synthesized from biodegradable polymers and chondrocytes. Biomaterials 15, 774-778. doi: 10.1016/0142-9612(94)90031-0

Romain, C., Garden, J. A., Trott, G., Buchard, A., White, A. J. P., and Williams, C. K. (2017). Di-zinc-aryl complexes: Co2 insertions and applications in polymerisation catalysis. Chem. Eur. J. 23, 7367-7376. doi: 10.1002/chem.201701013

Sheldrick, G. M. (1996). Sadabs, Program for Area Detector Absorption Correction. Institute for Inorganic Chemistry, University of Göttingen, Germany.

Sheldrick, G. M. (1997). Shelxtl-97, Program for Refinement of Crystal Structures. University of Göttingen, Germany.

Sheldrick, G. M. (2015). Crystal structure refinement with shelxl. Acta Crystallogr., Sect. C 71, 3-8. doi: 10.1107/S2053229614024218

Spek, A. L. (2003). Platon - A Multipurpose Crystallographic Tool. Utrecht University.

Spek, A. L. (2015). Platon squeeze: a tool for the calculation of the disordered solvent contribution to the calculated structure factors. Acta Crystallogr. Sect. C 71, 9-18. doi: 10.1107/S2053229614024929

Tsaroucha, M., Aksu, Y., Irran, E., and Driess, M. (2011). Synthesis of stannylsubstituted zn4o4 cubanes as single-source precursors for amorphous tindoped zno and zn2sno 4 nanocrystals and their potential for thin film field effect transistor applications. Chem. Mater. 23, 2428-2438. doi: 10.1021/cm20 $0282 \mathrm{w}$
Vitanova, D. V., Hampel, F., and Hultzsch, K. C. (2005). Rare earth metal complexes based on $\beta$-diketiminato and novel linked bis( $\beta$-diketiminato) ligands: Synthesis, structural characterization and catalytic application in epoxide/co2-copolymerization. J. Organomet. Chem. 690, 5182-5197. doi: 10.1016/j.jorganchem.2005.03.066

Wheaton, C. A., Hayes, P. G., and Ireland, B. J. (2009). Complexes of mg, ca and zn as homogeneous catalysts for lactide polymerization. Dalton Trans. 4832-4846. doi: 10.1039/b819107g

Wiecko, M., Roesky, P. W., Burlakov, V. V., and Spannenberg, A. (2007). Bis(phosphinimino)methanides as ligands in divalent samarium chemistry: synthesis, structures and catalysis. Eur. J. Inorg. Chem. 2007, 876-881. doi: 10.1002/ejic.200600947

Wu, J., Yu, T.-L., Chen, C.-T., and Lin, C.-C. (2006). Recent developments in main group metal complexes catalyzed/initiated polymerization of lactides and related cyclic esters. Coord. Chem. Rev. 250, 602-626. doi: 10.1016/j.ccr.2005.07.010

Wu, K.-M., Huang, C.-A., Peng, K.-F., and Chen, C.-T. (2005). Palladacycles bearing pendant benzamidinate ligands as catalysts for the suzuki and heck coupling reactions. Tetrahedron 61, 9679-9687. doi: 10.1016/j.tet.2005.06.069

Yao, W., Mu, Y., Gao, A., Su, Q., Liu, Y., and Zhang, Y. (2008). Efficient ring-opening polymerization of $\varepsilon$-caprolactone using anilido-imine-aluminum complexes in the presence of benzyl alcohol. Polymer 49, 2486-2491. doi: 10.1016/j.polymer.2008.03.035

Zhang, H., Cai, Q., and Ma, D. (2005). Amino acid promoted cui-catalyzed c-n bond formation between aryl halides and amines or $\mathrm{n}$-containing heterocycles. J. Org. Chem. 70, 5164-5173. doi: 10.1021/jo0504464

Zheng, Z., Elmkaddem, M. K., Fischmeister, C., Roisnel, T., Thomas, C. M., Carpentier, J.-F., et al. (2008). Synthesis of new dipyridinylamine and dipyridinylmethane ligands and their coordination chemistry with mg(ii) and zn(ii). New J. Chem. 32, 2150-2158. doi: 10.1039/b807258b

Conflict of Interest Statement: The authors declare that the research was conducted in the absence of any commercial or financial relationships that could be construed as a potential conflict of interest.

Copyright (C) 2019 Chen, Chen, Li and Chen. This is an open-access article distributed under the terms of the Creative Commons Attribution License (CC BY). The use, distribution or reproduction in other forums is permitted, provided the original author(s) and the copyright owner(s) are credited and that the original publication in this journal is cited, in accordance with accepted academic practice. No use, distribution or reproduction is permitted which does not comply with these terms. 